\title{
Psychosocial factors at work and sickness absence in the Gazel cohort: a prospective study
}

\author{
Isabelle Niedhammer, Isabelle Bugel, Marcel Goldberg, Annette Leclerc, Alice Guéguen
}

\begin{abstract}
Objective-To test whether psychosocial factors at work are predictors of rates of sickness absence.

Methods-The study population consisted of middle aged men and women employed by the French national electricity and gas company (EDF-GDF) in various occupations and followed up since 1989 by annual self administered questionnaires and independent data obtained from the medical and personnel departments of EDF-GDF. The 1995 questionnaire provided information about three psychosocial work factors: psychological demands, decision latitude, and social support at work. Sickness absence data were provided by the company's social security department. The occurrence of spells and days of absence in the 12 months after completion of the 1995 questionnaire was studied. Potential confounding variables were age, smoking, alcohol, and marital status, assessed in the 1995 questionnaire, and educational level and occupation, assessed from data provided by the personnel department. This study was restricted to the 12555 subjects of the initial cohort who were still working and answered the self administered questionnaire in 1995.

Results-Low levels of decision latitude were associated with more frequent and longer sickness absences among men and women. Low levels of social support at work increased the numbers of spells and days of absence among men only. These associations weakened after adjustment for potential confounding factors, but remained significant.

Conclusion-The study indicates that psychosocial factors at work, especially decision latitude, are predictive of sickness absence.

(Occup Environ Med 1998;55:735-741)
\end{abstract}

Hôpital National de

Saint-Maurice, France

I Niedhammer

I Bugel

M Goldberg

A Leclerc

A Guéguen

Correspondence to: Dr Isabelle Niedhammer, INSERM U88, Hôpital National de Saint-Maurice, 14 rue du Val d'Osne,

F-94415 Saint-Maurice

Cedex, France. Fax 0033

451838 89; email

i.niedhammer@

st-maurice.inserm.fr

Accepted 10 July 1998

Sickness absence is thought to have a multifactorial aetiology, in which illness and injury may be two of many causes. In the literature, several of the factors have proved to be associated with sickness absence, including societal conditions (social insurance and security, economic fluctuations, etc), conditions specific to a given workplace or organisation (policy towards the personnel, size, and type of industry), occupational conditions - such as physical, chemical, and psychosocial stressors, seniority, edu- cational level, and occupation - and social and demographic characteristics - that is, sex, age, marital status, number of children, social network, commuting distance to work, smoking habits, type of personality, and health. ${ }^{1-4}$ Several authors have shown that sickness absence (especially long spells of absence or medically certified absence) can be an indicator of general health. ${ }^{25}$ Other authors have found sickness absence to be a reliable indicator of subsequent serious morbidity. ${ }^{6}$ Because sickness absenteeism is strongly related to health and has an important economic impact in costs of health insurance and loss of productivity, identification of the predictors of absenteeism is essential as a guide to preventive measures.

Psychosocial work environment, in particular job strain as defined by the combination of high levels of psychological demands and low levels of decision latitude, has been found to be an important contributor to health, especially cardiovascular health. ${ }^{8}$ Some authors have reported an increased risk of sickness absence among workers exposed to adverse psychosocial factors at work, especially low levels of decision latitude. ${ }^{3-11}$

The objective of our present study was to establish whether psychosocial factors at work are predictors of subsequent sickness absence, in a prospective cohort of men and women employed by the French national company Electricité De France - Gaz De France (EDFGDF) in a wide variety of occupations.

\section{Subjects and methods}

STUDY POPULATION

The Gazel cohort, which was established in January 1989, originally included 20624 subjects working at EDF-GDF, comprising men aged 40-50 and women aged 35-50 at baseline. ${ }^{12}{ }^{13}$ Since 1989 , this cohort has been followed up by means of a yearly self administered questionnaire, and by the collection of independent data from the personnel and medical departments of EDF-GDF. Research on several dimensions of health has been conducted in this cohort. ${ }^{14-17}$
PSYCHOSOCIAL FACTORS AT WORK

In 1995 the self administered questionnaire included 16 items about psychosocial aspects of work. The items were based on the questionnaires of Karasek et al and Johnson et $a l,{ }^{18-20}$ and were selected as being particularly suitable for measuring job stress in a heterogeneous population. Three psychosocial work factors were included (appendix): psychological demands (a five item indicator measuring 
Table 1 Study population in 1995

\begin{tabular}{|c|c|c|c|c|c|}
\hline & & \multicolumn{2}{|c|}{$\begin{array}{l}\text { Women } \\
(n=3490)\end{array}$} & \multicolumn{2}{|c|}{$\begin{array}{l}\text { Men } \\
(n=9065)\end{array}$} \\
\hline & & $n$ & $\%$ & $n$ & $\%$ \\
\hline \multicolumn{6}{|l|}{ Age (y): } \\
\hline Women & Men & & & & \\
\hline $42-44$ & & 872 & 25.0 & - & - \\
\hline $45-49$ & $47-49$ & 1543 & 44.2 & 4268 & 47.1 \\
\hline $50-54$ & $50-54$ & 917 & 26.3 & 4304 & 47.5 \\
\hline $55-56$ & $55-56$ & 158 & 4.5 & 493 & 5.4 \\
\hline \multicolumn{6}{|l|}{ Smoking: } \\
\hline \multicolumn{2}{|c|}{ Non-smokers } & 2256 & 65.3 & 3627 & 40.2 \\
\hline \multicolumn{2}{|c|}{ Smokers } & 554 & 16.0 & 1892 & 21.0 \\
\hline Ex-smo & & 645 & 18.7 & 3498 & 38.8 \\
\hline \multicolumn{6}{|l|}{ Alcohol: } \\
\hline \multicolumn{2}{|c|}{ Abstainers } & 797 & 23.0 & 710 & 7.9 \\
\hline \multicolumn{2}{|c|}{ Light drinkers } & 1841 & 53.2 & 4961 & 55.0 \\
\hline \multicolumn{2}{|c|}{ Moderate drinkers } & 691 & 20.0 & 2070 & 23.0 \\
\hline \multicolumn{2}{|c|}{ Heavy drinkers } & 130 & 3.8 & 1275 & 14.1 \\
\hline \multicolumn{6}{|c|}{ Marital status: } \\
\hline \multicolumn{2}{|l|}{ Single } & 236 & 6.8 & 188 & 2.1 \\
\hline \multicolumn{2}{|c|}{ Married } & 2389 & 68.4 & 8066 & 89.0 \\
\hline \multicolumn{2}{|c|}{ Cohabiting } & 220 & 6.3 & 305 & 3.4 \\
\hline \multicolumn{2}{|c|}{ Separated } & 73 & 2.1 & 93 & 1.0 \\
\hline \multicolumn{2}{|c|}{ Divorced } & 445 & 12.8 & 342 & 3.8 \\
\hline \multicolumn{2}{|c|}{ Widowed } & 127 & 3.6 & 68 & 0.7 \\
\hline \multicolumn{6}{|c|}{ Educational level: } \\
\hline \multicolumn{2}{|c|}{ Primary } & 212 & 6.1 & 413 & 4.6 \\
\hline \multicolumn{2}{|c|}{ Lower vocational } & 1709 & 49.0 & 4617 & 50.9 \\
\hline Lower s & ondary & 661 & 18.9 & 1129 & 12.5 \\
\hline Uppers & condary & 406 & 11.6 & 599 & 6.6 \\
\hline Upper & cational & 196 & 5.6 & 638 & 7.0 \\
\hline Univers & & 306 & 8.8 & 1668 & 18.4 \\
\hline Occupatic & al group: & & & & \\
\hline $\begin{array}{l}\text { Teachin } \\
\text { professi }\end{array}$ & $\begin{array}{l}\text { and health } \\
\text { als }\end{array}$ & - & - & 118 & 1.3 \\
\hline Manage & & 245 & 7.0 & 1535 & 17.0 \\
\hline Engine & & 174 & 5.0 & 2054 & 22.7 \\
\hline $\begin{array}{l}\text { Health } \\
\text { profe }\end{array}$ & $\begin{array}{l}\text { d social work associate } \\
\text { onals }\end{array}$ & 72 & 2.1 & - & - \\
\hline $\begin{array}{l}\text { Admini } \\
\text { profe }\end{array}$ & $\begin{array}{l}\text { ative associate } \\
\text { onals }\end{array}$ & 1946 & 56.0 & 1069 & 11.9 \\
\hline $\begin{array}{r}\text { Physica } \\
\text { scien }\end{array}$ & $\begin{array}{l}\text { engineering and life } \\
\text { associate professionals }\end{array}$ & - & - & 518 & 5.7 \\
\hline Foreme & & 363 & 10.4 & 2768 & 30.7 \\
\hline Clerks & & 677 & 19.5 & 263 & 2.9 \\
\hline Skilled & dustrial workers & - & - & 374 & 4.1 \\
\hline Craftsm & & - & - & 334 & 3.7 \\
\hline Psycholog & al demands: & & & & \\
\hline Low & & 1404 & 43.0 & 4774 & 54.8 \\
\hline High & & 1863 & 57.0 & 3934 & 45.2 \\
\hline Decision 1 & itude: & & & & \\
\hline High & & 1581 & 47.8 & 4411 & 50.2 \\
\hline Low & & 1724 & 52.2 & 4372 & 49.8 \\
\hline Social sup & ort at work: & & & & \\
\hline High & & 1552 & 45.8 & 4268 & 48.1 \\
\hline Low & & 1839 & 54.2 & 4601 & 51.9 \\
\hline
\end{tabular}

job demands, time pressures, and conflicting demands), decision latitude (a six item indicator measuring the subject's influence on or control over his or her work, job variety, and the possibilities for learning new skills) and social support at work (a five item indicator measuring contacts with coworkers during work and leisure). Factorial validity was evaluated by principal factor analysis with orthogonal Varimax rotation; our results were consistent with the dimensions expected from the theory. Internal consistency was acceptable, Cronbach's $\alpha$ coefficients were 0.69 for psychological demands, 0.65 for decision latitude, and 0.52 for social support at work. The values for

Table 2 Sickness absence among men and women

\begin{tabular}{lll}
\hline & $\begin{array}{l}\text { Women } \\
(n=3490)\end{array}$ & $\begin{array}{l}\text { Men } \\
(n=9065)\end{array}$ \\
\hline Spells of absence $(\mathrm{n})$ & 3436 & 4524 \\
Rate of spells of absence / 100 person-years & 98.45 & $49.91^{\star \star \star}$ \\
Rate of days of absence / 100 person-years & 1450.00 & $808.05^{\star \star \star}$ \\
\hline
\end{tabular}

$\star \star \star \mathrm{p}<0.001$ all the items about each index were summed, and the summary distribution of values for each index was then dichotomised at the median, for use in analysis.

\section{SICKNESS ABSENCE DATA}

Sickness absence data were provided by the social security department of EDF-GDF which set up the database in 1975. This data base includes information on all the health problems of the company personnel: sickness absence, work accidents, occupational diseases, worker disability, and death. The data collection network, content, and mode of operation of the database have been described in detail elsewhere. ${ }^{21}$ The present study was about sickness absence - that is, all spells of absence for medical reasons. An original aspect of this social security system is that, theoretically, there is compulsory verification of any certified spell of absence; this makes it possible to establish a diagnosis for the illness which led to the absence each time it occurs. Verification is carried out by the medical doctors of the social security department. Consequently, the date, duration, and diagnosis of each spell of absence are known.

Results are presented for sickness absence during a 1 year time window that followed the 1995 self administered questionnaire, for subjects still working during this period-that is, who had not died, left the company, or retired during this follow up period. We computed the numbers of spells and days of absence to measure the frequency and duration of sickness absence. Thus the study design is prospective, in which we examine predictors of subsequent sickness absence.

DEMOGRAPHIC, BEHAVIOURAL, AND

OCCUPATIONAL CHARACTERISTICS

Demographic and behavioural characteristics based on the self administered questionnaire of 1995 comprised age, smoking, alcohol, marital status, and number of children. Smoking was defined by consumption of at least one cigarette a day. Alcohol consumption was based on frequency (number of days a week), quantity (glasses a day), and type consumed (wine, beer, or spirits). Drinkers were classified into four categories: abstainers, light drinkers (one to 13 drinks a week for men and one to six drinks a week for women), intermediate drinkers (14-27 drinks a week for men and seven to 20 drinks a week for women), and heavy drinkers ( $\geqslant 28$ drinks a week for men and $\geqslant 21$ drinks a week for women). Information about educational level and occupation was supplied by the personnel department of EDF-GDF.

\section{STATISTICAL METHODS}

For each subject, we recorded the numbers of spells and days of sickness absence. The rates of absence computed from these data were expressed /100 person-years - that is, the number of spells $/ 100$ person-years and the number of days of absence /100 person-years. As risk factors for sickness absence may differ, depending on the frequency of spells of 
Table 3 Subsequent sickness absence according to demographic, behavioural, and occupational characteristics

\begin{tabular}{|c|c|c|c|c|}
\hline & \multicolumn{2}{|c|}{ Women $(n=3490)$} & \multicolumn{2}{|c|}{$\operatorname{Men}(n=9065)$} \\
\hline & $\begin{array}{l}\text { Spells of } \\
\text { absence } \\
R R\end{array}$ & $\begin{array}{l}\text { Absence } \\
\text { days } \\
R R\end{array}$ & $\begin{array}{l}\text { Spells of } \\
\text { absence } \\
R R\end{array}$ & $\begin{array}{l}\text { Absence } \\
\text { days } \\
R R\end{array}$ \\
\hline \multicolumn{5}{|l|}{ Age (y): } \\
\hline $42-44$ & 1 & 1 & - & - \\
\hline $45-49$ & 1.10 & $1.37^{\star \star}$ & 1 & 1 \\
\hline $50-54$ & $1.19^{\star \star}$ & $1.69^{\star \star \star}$ & 1.02 & 1.10 \\
\hline $55-56$ & 1.01 & $1.74^{\star \star}$ & 0.86 & 1.19 \\
\hline \multicolumn{5}{|l|}{ Smoking: } \\
\hline Non-smokers & 1 & 1 & 1 & 1 \\
\hline Smokers & $1.26^{\star \star \star}$ & $1.26^{\star}$ & $1.24^{\star \star \star}$ & $1.45^{\star \star \star}$ \\
\hline Ex-smokers & 1.03 & 1.05 & $1.10^{\star}$ & 1.06 \\
\hline \multicolumn{5}{|l|}{ Alcohol: } \\
\hline Abstainers & 1.10 & $1.29^{\star \star}$ & $1.52^{\star \star \star}$ & $2.06^{\star \star \star}$ \\
\hline Light drinkers & 1 & 1 & 1 & 1 \\
\hline Moderate drinkers & 0.97 & 0.82 & 1.06 & 1.08 \\
\hline Heavy drinkers & 1.05 & 1.06 & $1.12^{\star}$ & 1.02 \\
\hline \multicolumn{5}{|l|}{ Marital status: } \\
\hline Single & $0.79^{\star}$ & $0.68^{\star}$ & $1.44^{\star \star}$ & $1.49^{\star}$ \\
\hline Married & 1 & 1 & 1 & 1 \\
\hline Cohabiting & 1.16 & 1.07 & 1.10 & 1.07 \\
\hline Separated & 0.98 & $1.59^{\star}$ & $1.61^{\star \star}$ & $2.76^{\star \star \star}$ \\
\hline Divorced & $1.40^{\star \star \star}$ & $1.44^{\star \star \star}$ & $1.25^{\star}$ & $1.49^{\star \star}$ \\
\hline Widowed & 1.08 & 1.05 & $0.42^{\star}$ & 0.28 \\
\hline \multicolumn{5}{|l|}{ Educational level: } \\
\hline Primary & $2.02^{\star \star \star}$ & $2.86^{\star \star \star}$ & $2.97^{\star \star \star}$ & $2.87^{\star \star \star}$ \\
\hline Lower vocational & $1.75^{\star \star \star}$ & $2.21^{\star \star \star}$ & $1.95^{\star \star \star}$ & $1.69^{\star \star \star}$ \\
\hline Lower secondary & $1.79^{\star \star \star}$ & $2.14^{\star \star \star}$ & $2.01^{\star \star \star}$ & $2.01^{\star \star \star}$ \\
\hline Upper secondary & $1.80^{\star \star \star}$ & $1.70^{\star}$ & $1.68^{\star \star \star}$ & $1.43^{\star}$ \\
\hline Upper vocational & $1.35^{\star}$ & 1.57 & $1.37^{\star \star}$ & 1.17 \\
\hline University & 1 & 1 & 1 & 1 \\
\hline \multicolumn{5}{|l|}{ Occupation: } \\
\hline Teaching and health professionals & - & - & 1.25 & $2.17^{\star}$ \\
\hline Managers & 1 & 1 & 1 & 1 \\
\hline Engineers & 0.87 & 0.48 & 1.05 & 0.99 \\
\hline $\begin{array}{l}\text { Health and social work associate } \\
\text { professionals }\end{array}$ & 1.45 & 1.36 & - & - \\
\hline Administrative associate professionals & $1.96^{\star \star \star}$ & $1.60^{\star}$ & $2.06^{\star \star \star}$ & $2.52^{\star \star \star}$ \\
\hline $\begin{array}{l}\text { Physical, engineering and life science } \\
\text { associate professionals }\end{array}$ & - & - & $2.42^{\star \star \star}$ & $2.73^{\star \star \star}$ \\
\hline Foremen & $1.96^{\star \star \star}$ & 1.47 & $1.96^{\star \star \star}$ & $2.34^{\star \star \star}$ \\
\hline Clerks & $2.76^{\star \star \star}$ & $2.53^{\star \star \star}$ & $3.71^{\star \star \star}$ & $5.06^{\star \star \star}$ \\
\hline Skilled industrial workers & - & - & $3.52^{\star \star \star}$ & $3.31^{\star \star \star}$ \\
\hline Craftsmen & - & - & $3.79^{\star \star \star}$ & $4.47^{\star \star \star}$ \\
\hline \multicolumn{5}{|l|}{ Psychological demands: } \\
\hline Low & 1 & 1 & 1 & 1 \\
\hline High & 1.00 & 0.96 & $0.91^{\star}$ & 0.99 \\
\hline \multicolumn{5}{|l|}{ Decision latitude: } \\
\hline High & 1 & 1 & 1 & 1 \\
\hline Low & $1.36^{\star \star \star}$ & $1.61^{\star \star \star}$ & $1.61^{\star \star \star}$ & $1.67^{\star \star \star}$ \\
\hline \multicolumn{5}{|l|}{ Social support at work: } \\
\hline High & 1 & 1 & 1 & 1 \\
\hline Low & 1.03 & $1.19^{\star}$ & $1.25^{\star \star \star}$ & $1.26^{\star \star \star}$ \\
\hline
\end{tabular}

${ }^{\star} \mathrm{p}<0.05 ;{ }^{\star \star} \mathrm{p}<0.01 ;{ }^{\star \star \star} \mathrm{p}<0.001 . \mathrm{RR}=$ Rate ratio.

absence and the duration of sickness absence, these two indicators were analysed separately.

The numbers of spells of sickness absence and days of absence are a form of counted data. Such counts of events are assumed to take the values of $0,1,2, \ldots$ without an upper limit. The Poisson distribution has only one adjustable parameter-namely, the mean $\mu$-which must be positive. Therefore, log linear Poisson regression models were fitted to the present data. ${ }^{22}$ It was assumed that for each subject, these dependent variables of spells and days of absence followed a Poisson distribution. The regression model for the $\mathrm{i}^{\text {th }}$ subject was:

$\log \left(\mu_{i}\right)=\alpha+\sum_{j=1}^{p} \beta_{j} x_{i j}$

$$
i=1, \ldots, n
$$

where $x_{i l}, \ldots, x_{i p}$ are the explanatory variables. Adjusted rate ratios (RRs) and their $95 \%$ confidence intervals (95\% CIs) were calculated. The Poisson model implies that the variance is equal to the mean. If the variance is greater than the mean after taking account of the explanatory variables, then the dispersion of the data is greater than that predicted by the Poisson model. Overdispersion was found for spells of sickness absence, and still more considerable overdispersion for days of absence. A scale parameter was therefore estimated for each model, by dividing the residual deviance by the number of degrees of freedom $(n-p)$, and was used to adjust the width of $95 \%$ CIS. ${ }^{22}$ Log linear Poisson regression models with overdispersion have already been used by others to analyse sickness absence. ${ }^{51123}$

Confounding variables included age, smoking, alcohol, marital status, number of children, educational level, and occupation. The three psychosocial factors at work were introduced into the models simultaneously, to permit assessment of their own effects. Interactions were also examined by including the three two way interaction terms: high demands and low latitude, high demands and low support, and low latitude and low support, and the three way interaction term: high demands, low latitude, and low support. Men and women were analysed separately. Statistical analysis was performed with the SAS statistical software package, ${ }^{24}$ and the Poisson regression models were fitted by the GENMOD procedure. $^{25}$

\section{Results}

STUDY POPULATION

Between 1989 and 1995, 222 of the subjects in the initial cohort of 20624 died, 2365 retired, and 38 left the company. Of the 17999 subjects still working in 1995, 13406 (74\%) answered the 1995 self administered questionnaire. One hundred and eighty subjects were excluded from the study because they were not working when the 1995 questionnaire had to be completed because of sickness absence, long illness, or disability. Of the 13226 working subjects who answered the questionnaire, another 18 died, 651 retired, and two left the company during the 12 months after its completion. The present study was therefore based on the 12555 subjects, comprising 9065 men and 3490 women, who were working during the 12 month follow up period. Further details concerning demographic, behavioural, and occupational characteristics of the population studied are given in table 1 . As reported previously ${ }^{17}$ decision latitude and psychological demands were associated with occupation; the higher the levels of occupation, the higher the levels of decision latitude, and psychological demands.

\section{SICKNESS ABSENCE}

Table 2 shows the rates of spells and days of absence/100 person-years for men and women. These rates of spells and days of absence were significantly higher in women than in men.

PSYCHOSOCIAL FACTORS AT WORK AND SICKNESS ABSENCE

Table 3 shows the RRs for spells and days of absence, according to the three psychosocial factors at work (psychological demands, deci- 
Table 4 Poisson regression analysis: adjusted rate ratios for spells of sickness absence

\begin{tabular}{|c|c|c|c|c|c|c|c|c|}
\hline & \multicolumn{4}{|c|}{ Women $(n=3076)$} & \multicolumn{4}{|c|}{$\operatorname{Men}(n=8374)$} \\
\hline & $R R^{\star}$ & $95 \% C I$ & $R R t$ & $95 \% C I$ & $R R^{\star}$ & $95 \% C I$ & $R R+$ & $95 \% C I$ \\
\hline \multicolumn{9}{|c|}{ Psychological demands: } \\
\hline Low & 1 & & 1 & & 1 & & 1 & \\
\hline High & 1.02 & 0.93 to 1.12 & 1.03 & 0.94 to 1.14 & 0.93 & 0.86 to 1.01 & 1.01 & 0.93 to 1.10 \\
\hline \multicolumn{9}{|c|}{ Decision latitude: } \\
\hline High & 1 & & 1 & & 1 & & 1 & \\
\hline Low & 1.37 & 1.24 to 1.50 & 1.19 & 1.07 to 1.31 & 1.58 & 1.46 to 1.72 & 1.22 & 1.12 to 1.33 \\
\hline \multicolumn{9}{|c|}{ Social support at work: } \\
\hline High & 1 & & 1 & & 1 & & 1 & \\
\hline Low & 0.99 & 0.90 to 1.09 & 1.00 & 0.91 to 1.10 & 1.21 & 1.12 to 1.31 & 1.21 & 1.11 to 1.31 \\
\hline \multicolumn{9}{|c|}{$\begin{array}{l}R R^{\star}=\text { Rate ratio adjusted for age. } \\
R R+=\text { Rate ratio adjusted for age, }\end{array}$} \\
\hline \multicolumn{9}{|l|}{ Table 5} \\
\hline & \multicolumn{4}{|c|}{ Women $(n=3076)$} & \multicolumn{4}{|c|}{$\operatorname{Men}(n=8374)$} \\
\hline & $R R^{\star}$ & $95 \% C I$ & $R R t$ & $95 \% C I$ & $R R^{\star}$ & $95 \% C I$ & $R R t$ & $95 \% C I$ \\
\hline \multicolumn{9}{|c|}{ Psychological demands: } \\
\hline Low & 1 & & 1 & & 1 & & 1 & \\
\hline High & 0.97 & 0.82 to 1.15 & 0.95 & 0.81 to 1.13 & 1.02 & 0.88 to 1.17 & 1.11 & 0.96 to 1.28 \\
\hline \multicolumn{9}{|c|}{ Decision latitude: } \\
\hline High & 1 & & 1 & & 1 & & 1 & \\
\hline Low & 1.56 & 1.31 to 1.85 & 1.34 & 1.12 to 1.61 & 1.67 & 1.44 to 1.93 & 1.22 & 1.05 to 1.43 \\
\hline \multicolumn{9}{|c|}{ Social support at work: } \\
\hline High & 1 & & 1 & & 1 & & 1 & \\
\hline Low & 1.12 & 0.94 to 1.32 & 1.12 & 0.95 to 1.34 & 1.23 & 1.06 to 1.41 & 1.17 & 1.01 to 1.35 \\
\hline
\end{tabular}

$R^{\star}=$ Rate ratio adjusted for age.

$\mathrm{RR}+=$ Rate ratio adjusted for age, smoking, alcohol, marital status, educational level, and occupation.

sion latitude, and social support at work) and potential confounding variables. Decision latitude was a significant predictor of spells and duration of sickness absence for men and women. Men and women who reported high levels of decision latitude had $25 \%$ to $40 \%$ less of both spells and days of sickness absence than those with low levels of latitude. Social support at work was also a significant predictor of spells of absence in men and of duration of absence in both men and women. Men who reported high levels of social support at work had $20 \%$ less spells and days of absence than those with low levels of support. For women, the effects of social support at work were less marked; women with high levels of social support had about $15 \%$ less days of absence. Psychological demands were not a significant predictor of sickness absence in men or women.

Potentially confounding factors, age, smoking, alcohol, marital status, educational level, and occupation were significantly related to subsequent spells and days of absence. As the number of children was not significantly associated with sickness absence (not shown), it was not included in the multivariate analysis.

After simultaneously introducing the three psychosocial factors at work and adjusting for confounding variables, the effects of low levels of decision latitude and social support at work weakened, but the relations were still significant for decision latitude, for both men and women, and for social support at work for men (tables 4 and 5). Men and women who reported high levels of decision latitude had $15 \%-25 \%$ less of both spells and days of absence than those with low levels of latitude, and men with high levels of social support had $15 \%-20 \%$ less spells and days of absence than those with low levels of support. Psychological demands were not a significant predictor of sickness absence in men or women. Futhermore, no interaction was found between the three psychosocial factors at work and subsequent sickness absence.

\section{Discussion}

This prospective study showed that two of the three psychosocial factors at work-low levels of decision latitude for men and women, and low levels of social support at work for men-were significant predictors of subsequent sickness absence. They predicted both frequency and duration of sickness absence. Also, the associations between psychosocial work characteristics and such absence were markedly independent of potential confounding variables.

The Gazel cohort has several advantages for a study of this type.

Workers at EDF-GDF were chosen because of the stability of the Company's work force. Only 40 subjects $(<0.2 \%)$, who had resigned from the company, were lost to follow up between 1989 and 1996. The response rate (74\%) for the 1995 self administered questionnaire can be considered satisfactory. Moreover, among the 12555 subjects included in this study, there were no losses to follow up during the 12 month period after the completion of the questionnaire, because sickness absence data were provided by the social security department for all the subjects in an exhaustive manner. Futhermore, among the 20624 workers who gave their consent to participate in the project of the Gazel cohort in 1989, nobody has refused access to their records of sickness absence since then.

Regarding sickness absence, the fact that the study was based on a cohort of workers from the same company made it possible to examine this absence within an organisation with a uni- 
form policy towards absenteeism. In addition, the data concerning sickness absence were derived directly from the records of the social security department of EDF-GDF, which eliminated the potential bias involved in self reporting.

However, some limitations of the present results must be considered.

The assessment of psychosocial factors at work in 1995 was based on self reporting, which reflects only in part the objective work environment, as measured by external or independent evaluation. This assessment may therefore have been subject to a response bias. Firstly, the subject's perception of their psychosocial work environment may be more important than objective assessment, and secondly, no adequate objective measurement is available for the psychosocial work environment. Attempts to use a job exposure matrix have been made, but led to underestimation of variance within occupations. ${ }^{26}$ Our scale of social support at work is not completely adequate, as it only measures the frequency of contacts with coworkers, and not the satisfaction with the support received from either coworkers or the supervisor. Futhermore, psychosocial work variables which were assumed to be relatively stable were assessed at one time rather than on the person's cumulative work history. This could be a potential source of misclassification, but such misclassification is likely to be non-differential, so that the true relation between psychosocial work environment and sickness absence would have been underestimated.

To avoid any spurious association between psychosocial work variables and sickness absence due to confounding factors, our analyses were adjusted for most of the known risk factors. However, these analyses may not have taken adequate account of the many factors that affect sickness absence. Several authors ${ }^{2}$ have highlighted the complexity of different multivariate models of sickness absence, in particular risk factors which were not measured but might be important-such as those relating to work ethics, commitment to the organisation, or attitudes to the acceptable levels of sickness absence (the absence culture)-but it seems unlikely that these factors would completely explain the associations found here. Other authors noted that the association between psychosocial factors at work and sickness absence was still important, after adjustment for confounding variables. ${ }^{11}$ Furthermore, adjustment for confounding factors may constitute overcontrol and thus lead to underestimation of risks, because these factors - for example, smoking - may be part of the causal pathway linking exposure to psychosocial factors at work and sickness absence. Adjusting for occupation may also diminish the association between psychosocial factors at work and sickness absence because of the strong relation between occupation and psychosocial factors at work. As North et al noticed, ${ }^{11}$ the true association between psycho- social factors at work and sickness absence is probably between the unadjusted and adjusted RRs.

Despite these limitations, our results are consistent with those of previous studies, in which an association was reported between psychosocial factors at work and sickness absence. ${ }^{3-11}$ In particular, they agree with the findings of North et $a l^{11}$ showing the importance of low levels of decision latitude for subsequent sickness absence. Our results also underline the differences between men and women for the effects of psychosocial factors at work on sickness absence: thus, social support at work played a big part in subsequent sickness absence for men, but was not at all significant for women. This sex difference might partly be due to the fact that $80 \%$ of EDF-GDF employees are male. Thus women may be more isolated in a male dominated environment than men, and the effects of social support at work may be less important for women. Futhermore, analyses carried out with the quartiles of the scores of the three psychosocial factors at work supported the hypothesis of a dose-response relation between the two psychosocial factors of decision latitude and social support at work and sickness absence in men.

North et $a l^{11}$ examined the association between the psychosocial work environment and subsequent rates of sickness absence with two indicators: short spells of absence $(\leqslant 7$ days) and long spells ( $>7$ days). They chose these indicators because spells of absence exceeding 7 calendar days require a medical certificate. Also, it can be assumed that long spells of absence are more closely related to health than short spells. ${ }^{25}$ However, as a medical certificate is required for all spells of absence at EDF-GDF, this threshold of 7 days would have been arbitrary in our cohort. These two indicators ( $>7$ or $\leqslant 7$ days of absence) were also studied here, but the results were similar, as a low level of decision latitude proved to be a strong predictor of both short and long spells of absence for men and women, and a low level of social support at work increased the risk of both for men only.

Our study showed that other non-work related risk factors as well as occupational factors play a part in subsequent sickness absence. Women were more often absent from work, for longer periods, as reported by others. ${ }^{1}{ }^{423} 27-30$ The number of children was not associated with sickness absence for men or women in our study, contrary to other studies, ${ }^{28}$ in which sickness absence increased with an increasing number of dependent children among women. However, it can be supposed that the association between the number of children and sickness absence may depend on the age of children. The effects of the presence of children on sickness absence may therefore be less important in our population of women who were $\geqslant 42$ years old in 1995 . We found differences between sickness absence for different age groups, and in particular, a significant trend towards an age related increase in the duration of sickness absence among men and 
women in the multivariate analysis (not shown), in agreement with the results of other authors. ${ }^{1530}$ However, our results are limited by the fact that the range of age was small in the Gazel cohort. Futhermore, people aged $\geqslant 55$ are more likely to have retired if their work was physically strenuous, because 55 years is the legal age for retirement at EDF-GDF, a fact which may lead to underestimation of the effects of age on sickness absence, because of the healthy worker effect. Smoking was a strong predictor of spells and duration of sickness absence for men and women; thus, smokers ran an increased risk of sickness absence, and male ex-smokers were liable to more spells of absence. Alcohol was predictive of sickness absence in men and women; abstainers were more likely to have frequent and long sickness absence. North $e t a l^{23}$ also found that both men and women smokers had higher rates of sickness absence than non-smokers, and reported an association between alcohol consumption and sickness absence in men. We found that marital status was a predictor of sickness absence in both men and women, with divorced women and separated men being at high risk, which is consistent with the results of previous studies. ${ }^{4728}$ Educational level was associated with sickness absence, but the patterns were different for men and women. Education remained a significant predictor of spells of sickness absence for men in the multivariate analysis, but was no longer significant for women. However, the number of days of absence was not related to educational level among men or women. Occupation was a strong predictor of subsequent sickness absence, and the lower the occupational level, the more spells of sickness absence and the longer their duration. Similar trends have already been reported by others. ${ }^{1} 452327-30$

\section{Conclusion}

Our results provide strong support for the predictive effects of psychosocial factors at work on sickness absence, especially the effects of low levels of decision latitude. As sickness absence has an important impact on the wellbeing of the population and on the economy, our findings underline the need for futher research on the occupational risk factors of sickness absence.

We thank the Medical Committee of EDF-GDF and all the participating workers of the Gazel cohort, who made the study participating workers of the Gazel cohort, who made the study
possible. Our thanks go also to Lisa F Berkman for her helpful possible. Our thanks go also to Lisa F Berkman for her helpful comments during preparation of the manuscript, to Mireille
Beaudoin and Simone David for their help in compiling the refBeaudoin and Simone David for their help in compiling the refscript.

1 Prins R, De Graaf A. Comparisons of sickness absence in

Prins R, De Graaf A. Comparisons of sickness absence in 1986;43:529-36.

2 Bourdonnais R, Vinet A. L'absence au travail comme indicateur de santé: signification, mesures et conditions d'utilisation. Rev Epidémiol Santé Publique 1989;37:173-82.

3 Kristensen TS. Sickness absence and work strain among Danish slaughterhouse workers: an analysis of absence from work regarded as coping behaviour. Soc Sci Med 1991;32:15-27.
4 Chevalier A, Goldberg M. L'absence au travail: indicateur social ou indicateur de santé ? Sci Soc Santé 1992;10:47-65.

5 Marmot M, Feeney A, Shipley M, et al. Sickness absence as a measure of health status and functioning: from the UK Whitehall II study. F Epidemiol Community Health 1995;49: 124-30.

6 Jenkins R. Minor psychiatric morbidity in employed young men and women and its contribution to sickness absence. Br f Ind Med 1985;42:147-54.

7 Dab W, Rochon J, Bernard L. L'absence au travail comme prédicteur de morbidité grave. Une double étude castémoins (infarctus du myocarde et accident du travail) dans une grande entreprise québécoise. Rev Epidémiol Santé Publique 1986;34:252-60.

8 Schnall PL, Landsbergis PA, Baker D. Job strain and cardiovascular disease. Annu Rev Public Health 1994;15: 381-411.

9 Karasek RA. Job demands, job decision latitude, and mental strain: implications for job redesign. Administrative Science Quarterly 1979;24:285-308.

10 Karasek R, Gardell B, Lindell J. Work and non-work correlates of illness and behaviour in male and female Swedish white collar workers. F Occup Behav 1987;8:187-207.

11 North FM, Syme SL, Feeney A, et al. Psychosocial work environment and sickness absence among British civil servants: the Whitehall II study. Am $\mathcal{F}$ Public Health 1996;86:332-40.

12 Goldberg M, Leclerc A, Chastang JF, et al. Mise en place d'une cohorte épidémiologique à Electricité De FranceGaz De France. Recrutement des volontaires. Rev Epidémiol Santé Publique 1990;38:265-8.

13 Goldberg M, Leclerc A, Chastang JF, et al. Mise en place d'une cohorte épidémiologique à Electricité De FranceGaz De France. Principales caractéristiques de l'échantillon. Rev Epidémiol Santé Publique 1990;38:37880 .

14 Ringa V, Ledésert B, Bréart G. Determinants of hormone replacement therapy among postmenopausal women enrolled in the French Gazel cohort. Osteoporosis Int 1994;4:16-20.

15 Boumendil E, Tubert-Bitter P. Depression-induced absenteeism in relation to antihyperlipidemic treatment: a study using Gazel cohort data. Epidemiology 1995;6:322-5.

16 Moneta GB, Leclerc A, Chastang JF, et al. Time-trend of sleep disorder in relation to night work: a study of sequential 1-year prevalences within the Gazel cohort. $\mathcal{F}$ Clin Epidemiology 1996;49:1133-41.

17 Niedhammer I, Goldberg M, Leclerc A, et al. Psychosocial work environment and cardiovascular risk factors in an occupational cohort in France. $\mathcal{F}$ Epidemiol Community Health 1998;52:93-100.

18 Karasek R, Theorell T. Healthy work: stress, productivity, and the reconstruction of working life. New York, NY: Basic Books, 1990

19 Johnson JV, Hall EM. Job strain, work place social support, and cardiovascular disease: a cross-sectional study of a random sample of the Swedish working population. Am f Public Health 1988;78:1336-42.

20 Johnson JV, Hall EM, Theorell T. Combined effects of job strain and social isolation on cardiovascular disease morbidity and mortality in a random sample of the Swedish male working population. Scand $\mathcal{F}$ Work Environ Health 1989;15:271-9.

21 Goldberg M, Blanc M, Chastang JF, et al. The health data base of a nationwide company-its use in epidemiological studies. 7 Occup Med 1982;24:47-52.

22 McCullagh P, Nelder JA. Generalised linear models. London: Chapman and Hall, 1983:127-40.

23 North F, Syme SL, Feeney A, et al. Explaining socioeconomic differences in sickness absence: the Whitehall II study. BMF 1993;306:361-6.

24 SAS Institute. SAS/STAT user's guide, release 6.03 edition. Cary, NC: SAS Institute, 1988:1028.

25 SAS Institute. SAS technical report P-243, SAS/STAT software: the GENMOD procedure, release 6.09. Cary, NC: SAS Institute, 1993:88.

26 Schwartz JE, Pieper CF, Karasek RA. A procedure for linking psychosocial job characteristics data to health surveys. Am f Public Health 1988;78:904-9.

27 Pines A, Skulkeo K, Pollak E, et al. Rates of sickness absenteeism among employees of a modern hospital: the role of demographic and occupational factors. Br f Ind Med 1985; 42:326-35.

28 Chevalier A, Luce D, Blanc C, et al. Sickness absence at the French National Electric and Gas Company. Br F Ind Med 1987;44:101-10

29 Alexanderson K, Leijon M, Akerlind I, et al. Epidemiology of sickness absence in a Swedish county in 1985, 1986, and 1987. Scand F Soc Med 1994;1:27-34.

30 Clark S, Elliott R, Osman J. Occupation and sickness absence. In: Occupation health. Office of population censuses and surveys health and safety executive. Series DS no. 10. The registrar general's decennial supplement for England and Wales. London: HMSO, 1995. 


\section{Appendix: Contents of the questionnaire} on psychosocial factors at work

Three characteristics of the psychosocial work environment - psychological demands, decision latitude, and social support at work - were assessed by means of 16 items. Answers were graded from 1 to 4 .

Psychological job demands:

My work requires me to work very fast

My work requires me to work very hard

I am asked to do too much work

I have enough time to do my work

I receive no conflicting demands

Decision latitude:

My work requires me to learn new skills

My work requires a high level of skills

My work requires creativity
My work is repetitive

I am free to decide what I am going to do on the job

I am free to decide the amount of work I am going to do

Social support at work:

Can you talk to your coworkers during breaks?

Can you leave your work to talk to your coworkers?

Does your work require you to have many contacts with your coworkers?

How often do you meet your coworkers outside the work place?

When did you last meet one of your coworkers at home?Am J Epidemiol 1992;135:1019-

41.

\section{Vancouver style}

All manuscripts submitted to Occup Environ Med should conform to the uniform requirements for manuscripts submitted to biomedical journals (known as the Vancouver style.)

Occup Environ Med, together with many other international biomedical journals, has agreed to accept articles prepared in accordance with the Vancouver style. The style (described in full in the $\mathcal{F} A M A[1]$ ) is intended to standardise requirements for authors, and is the same as in this issue.

References should be numbered consecutively in the order in which they are first mentioned in the text by Arabic numerals on the line in square brackets on each occasion the reference is cited (Manson[1] confirmed other reports[2][3][4][5]). In future references to papers submitted to Occup Environ Med should include: the names of all authors if there are three or less or, if there are more, the first three followed by et al; the title of journal articles or book chapters; the titles of journals abbreviated according to the style of Index Medicus; and the first and final page numbers of the article or chapter. Titles not in Index Medicus should be given in full.

Examples of common forms of references are:

1 International Committee of Medical Journal Editors. Uniform requirements for manuscripts submitted to biomed journals. IAMA 1993;269:2282-6.

2 Soter NA, Wasserman SI, Austen KF. Cold urticaria: release into the circulation of histmaine and eosinophil chemotactic factor of anaphylaxis during cold challenge. $N$ Engl F Med 1976;294:687-90.

3 Weinstein L, Swartz MN. Pathogenic properties of invading micro-organisms. In: Sodeman WA Jr, Sodeman WA, eds. Pathologic physiology, mechanisms of disease. Philadelphia: W B Saunders, 1974:457-72. 